\title{
Challenges of Burnout Prevention in Slovac SMEs- Focus on Optimal Employment
}

\section{Enikő Korcsmáros, Renáta Machová}

J. Selye University, Faculty of Econommics, Bratislavska str. 3322, 94501 Slovak Republic, korcsmarose@ujs.sk (corresponding author); machovar@ujs.sk

\begin{abstract}
Labor shortages have become widespread in Slovakia in recent years. Numerous studies deal with the difficulties of finding a skilled, motivated workforce and the difficulties of retantion. The aim of this study is to introduce the tools used by managers in $H R$ with special regard in examining the efforts companies make to prevent burnout. The study provides a statistical analysis of the results of primary data collection on a sample of 431 SMEs the current employment policy issues in Slovakia, with a particular focus on recruitment, motivation and retention. SMEs are the engine of the European Economy, which is why it is very important that this machinery works well, is able to produce continuously and thus contribute to the economic development of the country. One of the prerequisites for this is that the human resources available to them are properly managed. Our goal is to showcase the opportunities and tools that a manager or HR department uses when it comes to employing a company, and to try to find a solution for the problem of retaining an effective workforce. Based on the obtained data related to burnout syndrome, we can conclude that $76.38 \%$ of the surveyed companies address the issue of employee burnout. $86 \%$ of the employees are at risk of burnout, since burnout is the diesease of our modern civilization. $68 \%$ of the companies struggle with more than a $15 \%$ workforce fluctuation, which can be declared a loss for the company.
\end{abstract}

Keywords: employment; motivation tools; burnout syndrome; SMEs competitiveness; Slovakia

\section{Introduction}

Since SMEs are an engine of the European economy, it is important to create a well-functioning SME sector that contributes to economic development of the country [13]. One of the basic prerequisites for this condition is the availability of the properly managed human resources capital. Our objective is to introduce the opportunities and tools used by managers and HR when addressing the employment issue, and find the most appropriate solution for the problem of retaining an operational workforce. 
Increasing the employment and the level of employability are the most common measures to tackle the long-term unemployment in the EU and Slovakia, as well. Mutual effects can be achieved by integrating tools since economic growth and employment cannot be achieved in isolation.

Employment is a complex economic and social function, in which the specific and different approaches of both sciences should be applied [16]. Therefore, the labor market is a part, not only, of the economic, but of the social sector.

Employment policy is an external system of the labor market that makes the labor market function more harmoniously [1]. The social activities can be applied easily [16]. It is important to differentiate the employment policy and the labor market policy since different actors are involved and their issues require different solutions. While employment policy is more concerned with the labor market demand and regulation of the economy, the labor market policy is addressing the issue of unemployment and the social tensions resulting from the problem [5].

The definition of burnout was set by Maslach as "a psychological syndrome of emotional exhaustion, depersonalization, and reduced personal accomplishment" which occurs as a response to emotional and interpersonal stressors among individuals. [17] According to the studies deals with burnout perceived stress was positively correlated with all burnout dimensions but there is no significant correlation between gender and burnout. [20]

This work highlights key HR tools that can reduce burnout within the company. Section 2 explain the theoretical background of the problems and describe the 3 models of employment policy, Maslow's hierarchy of needs and in addiction to motivation, present the problem of burnout-syndrome and its stages. Methodology of our research is describe in Section 3. Section 4 presents the result of the research, including the main findings. The contribution of the article is to present and evaluate the burnout-syndrome among employees in Slovac SMEs. Section 5 presents the relevant conclusions.

\section{Theoretical Background}

The most important task of employment policy is to ensure ideal work conditions and possibilities in accordance with the employee abilities. The instruments of employment policy can help to meet the labor market supply and demand. The employees have to remain flexible to meet the labor market demand. They can find new jobs easier. These tools provide an opportunity to decrease the labor market supply in different sectors by decreasing training opportunities. It is also important to help those who have lost their jobs because of external circumstances [16]-[15]. 
Three (3) models of employment policy are distinguished. The first is the social model of full employment, which is primarily based on the socio-political perspectives. The state eliminates the unemployment by introducing compulsory employment. This is achieved by creating workplaces to meet the demand. The biggest disadvantage of the model is the phenomena of internal unemployment since it is creating a useless but employed workforce that results in decrease of the market mechanisms (decreasing performance, inadequate productivity, decreasing competitiveness). The second is the general model of employment, which is based on the autonomy of the labor market. It provides conditions for the business organizations to employ the amount of workforce they require. The principle of efficiency is applied. Since it is impossible to provide workplace for everyone, the unemployment cannot be eliminated. The last is the model of full employment. The main objective is the elimination of unemployment, uncertainty and discrimination. It focuses on utilizing the available workforce the most efficient way. [2]-[8] The elimination of unemployment and efficient utilization of workforce would be a primary social objective in order to achieve higher productivity. However, in dynamic economies a certain level of unemployment is unavoidable that should be managed without resulting in social tension [25].

Although employment policy is the driving force of labor market processes, it is not enough to find solution for all the emerging problems. The process can be influenced by applying other policy tools as well. [14] The economic policy can determine the path of the economic growth, influencing the demand on the labor market. Demographic trends and the ratio of economically active workforce can be influenced by the population policy. It also has impact on the labor supply. The income policy can influence the willingness to work. It can regulate the purchasing power and the demand. [10] The employment can be incentivized by applying financial and fiscal policy tools since the price level and the regulation of household income has impact on the productivity of the businesses and their labor demand. Employment policy is supported by social policy that helps the unemployed. [19] The workforce mobility can be enhanced by education policy. Increasing the duration of trainings and education can postpone the labor market entry. [21] The cooperation of labor market players can be supported by the work of different interest groups that might contribute to reduction of tension on the labor market. The law protects the employers by formulating rules supporting the conclusion or termination of the work contract [25].

Active and passive tools of employment policy are differentiated. The active tools are designed to achieve equilibrium of workforce supply and demand, and help the re-entry of unemployed on the labor market by supporting employment trainings and providing possibilities to start business activity. The mentioned tools incentivize the employment. The passive tools cannot influence the employment directly (e.g. unemployment benefit). They rather help the unemployed [5].

Retaining a workforce means using different motivational tools to keep the employee within the company. It is not a simple task, since numerous 
motivational tools are can be applied to motivate different types of employees. There are many motivational theories, which try to find the roots of human motivation. One of the oldest, the most controversial and undoubtedly the most influential is the theory of Maslow. Abraham Maslow was the author of the theory of motivation based on a hierarchy of needs. According to Maslow's Hierarchy of Needs, everybody is motivated by five needs.

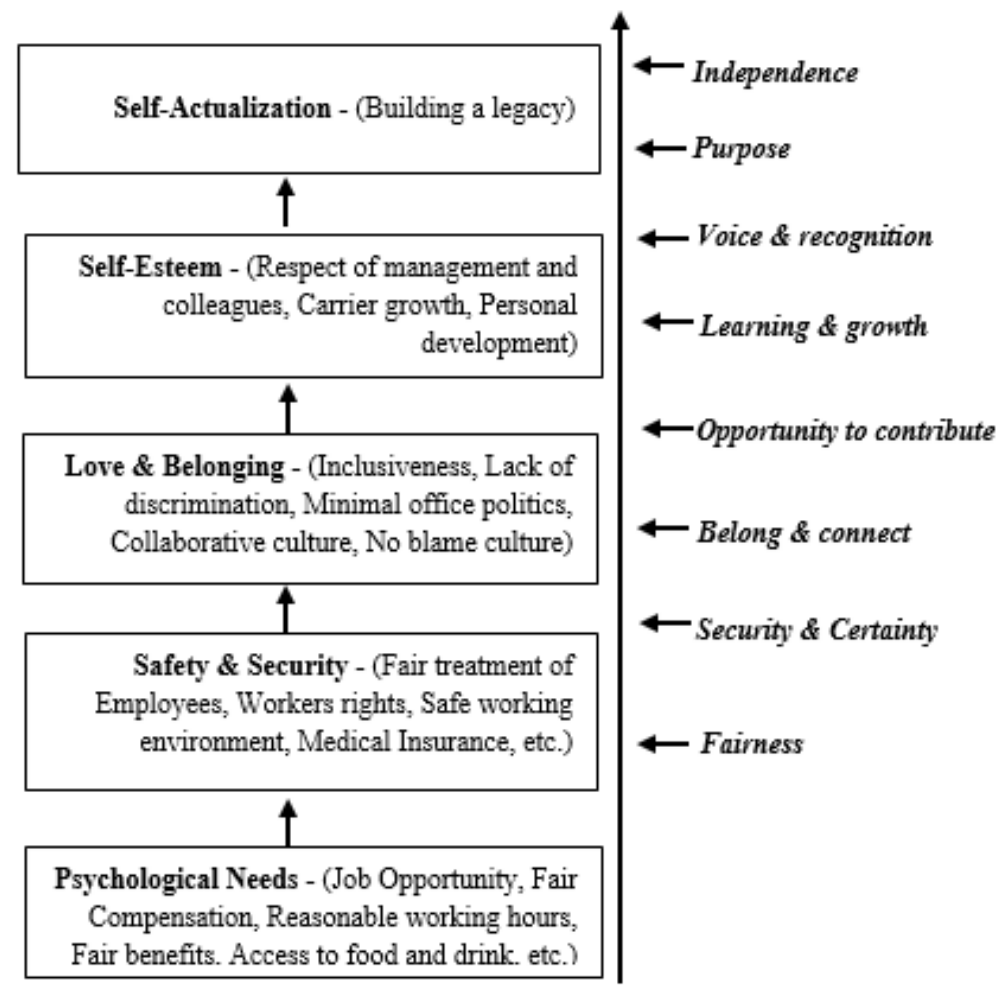

Figure 1

Maslow's Hierarchy of Needs in connection with employees' motivation

(Source: own editing based on [18])

Maslow stated that individuals must satisfy lower level needs before progressing to meet the higher level growth needs [18].

However, motivation by pay is adequate up to certain level, but not enough to progress and meet a higher level of satisfaction. Daniel H. Pink in his work The Surprising Truth about What Motivates Us explained that good salary is essential to retain the employee, but not enough to maintain an employee's motivation. Money has no long-term motivating effect. Pink emphasized that different motivational tools should be applied for the representatives of Generation $\mathrm{X}$ and Generation Y [23]. The employees should know that their work is important. 
There should be an internal incentive to complete the work, financial incentive is not enough to achieve employee satisfaction. If it is missing, the employees might be easily attracted by a slightly higher wage offered by competitors. [7] The motivational tools can be learned, but majority of the SME leaders underestimate the power of motivation. However, the leadership with incentives increases not only the productivity, but the employees have increased willingness to perform better [3].

In addition to motivation, there is another factor playing role in retaining or losing an employee. This factor is the burnout-syndrome. Burnout is a physical, mental and emotional exhaustion that occurs as a reaction to chronic workplace stress [27]. The long-term stress in SME sector is a result of overwork, unclear expectations, lack of feedback and workplace recognition, but also the workplace insecurity. The burnout-syndrome has different stages.

The first stage is characterized by over-enthusiasm, setting unrealistic goals and lively interaction with colleagues. The stage of idealism is followed by the phase of realism. The employee is still committed to his/her job; this phase is characterized by cooperation and interest in tasks.

The performance and interest start to decline in stagnation phase. The interaction focuses only on the necessary issues. In stage of frustration, the individual is experiencing failure and a sense of powerlessness. The efforts do not visibly pay off and the performance is falling. They refuse the help of colleagues and all of those they work together with become annoying. The last stage is apathy. Despair and disillusionment occur, the interaction falls into the minimum and the individual is resigned and indifferent. The relationship with colleagues is becoming hostile, while the individual loses all hope and trust in the organization. It is important to emphasize that burnout is a cyclically repetitive process, so it does not end with the fifth stage, but different stages of burnout will repeat [27][6]. The process usually ends with the employee leaving the company. Either the employees resign to escape the situation or they are dismissed because of falling performance. The stages of burnout are presented in the following figure (Fig. 2).

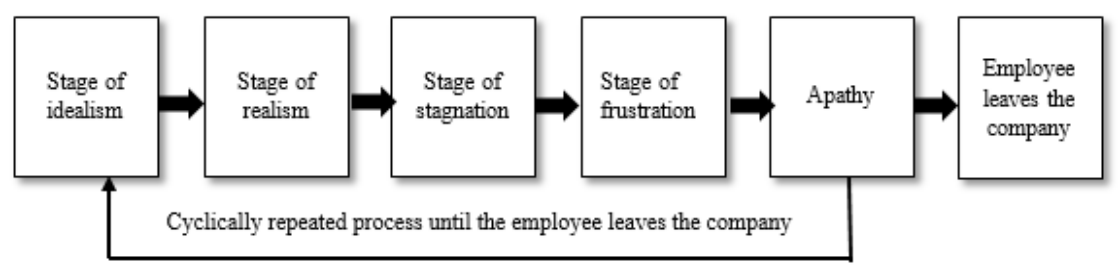

Figure 2

Flowchart - Stages of burnout

(Source: own editing, based on [27]) 
Burnout has a very serious impact on the individual, the team and the organization as well. It is the most common type of stress-related illnesses, affecting $86 \%$ of the Hungarian employees [22]. This is why it is important to put more emphasis on prevention. The prevention can be examined at organizational and individual level. Our study will examine prevention at organizational level. The easiest way to avoid burnout is to minimize or eliminate the possible roots of burnout. It means that managers of organizations should promote healthy work-life balance and will not put additional burden on the employee. The manager should clearly define the tasks and responsibilities; provides a regular feedback about the employee performance. [24] Employees are involved in tasks and issues closely related to their work. They have to be informed how their activity is contributing to the company strategy. A pleasant workplace atmosphere should be created, which can be achieved by organizing team building programs [11].

Motivation and strategies applied to prevent burnout are two important factors if companies would like to retain the workforce. A complete paradigm shift is required by SME leaders to understand that retaining workforce is an essential task. Nowadays, when most of the companies are struggling with labor shortage, retaining a workforce is seen as a new form of the recruitment process [12]. This is the reason why we considered it important to formulate our Assumption 1 to analyze if the widespread use of motivational tools has positive influence on the prevention of burnout syndrome.

\section{Methods and Methodology}

The theoretical background of the issue was defined in the prevoiuse section of the article, so we are currently dealing with methodological issue. The aim of the study is to introduce the tools used by managers for HR in special regard to examine the efforts the companies make to prevent burnout. The goal of the research is to address the main employment issues of SMEs in terms of retaining the workforce. The recruitment strategies of SMEs and the strategies for retaining employees will be examined. The sub-goals of the research is to analyze what type of employment patterns are offered by SMEs, how flexible they are, what kind of motivational tools are used, are there any forms of atypical employment offered and what kind of measures are taken to prevent workforce leaving the company. We also investigate whether the employers consider the work-life balance important, do they feel the employees motivated and take measures to prevent burnout, which is one of the major social problems nowadays resulting in employees leaving the company. Studying the theoretical background to the issue, all of the mentioned aspects are important in order to retain the workforce.

A questionnaire survey was intsigated in Slovakia (February-April, 2018) to collect the primary data. The questionnaire contained 23 questions, mapping the 
basic information about the companies and the motivational tools applied to retain their employees. A snowball method was used in the questionnaire survey. We randomly selected 200 SMEs in Slovakia to whom we sent the questionnaire in form of direct mail and ask them to forward it to other SMEs as well. The total number of submitted questionnaires form SMEs was 503, but 72 questionnaires had to be excluded, since they were submitted by self-entrepreneurs running their company on their own without employing other employees. The analysis of obtained data is based on the remaining 431 questionnaires. The authors used the SPSS software statistical program to investigate the proposed relations.

The present study introduces only partial data, which is closely connected to Assumption 1. According to Assumption 1, the widespread use of motivational tools has positive influence on the prevention of burnout syndrome.

In addition to basic descriptive statistical methods (distribution, standard deviation, modus) the Pearson's Chi-square and Cramer V were used to analyze the obtained data.

The Pearson's Chi-square Test expresses the statistical significance of the relationship between the two nominal variables.

$$
x^{2}=\sum_{\text {total cellis }} \frac{\left(f_{0}-f_{e}\right)^{2}}{f_{e}}
$$

The relationship is primarily based on the comparison of expected $\left(f_{e}\right)$ and observed $\left(\mathrm{f}_{0}\right)$ values.

To express the strength of the relationship, the Cramer V indicator was used, where $\mathrm{N}$ refers to size of the sample and $\mathrm{k}$ expresses the number of categories [9]:

$$
V=\sqrt{\frac{\chi^{2}}{N(k-1)}}
$$

The Cramer $\mathrm{V}$ given this index ranges from 0 to +1 . The higher the indicator is, the stronger the association is.

\section{Primary Data Assessment}

With regard to basic characteristics of the surveyed sample, we should emphasize that the vast majority of the businesses surveyed have been conducting their business activity for less than 10 years $(27.6 \%$ - 0-5 years, $30.4 \%$ - 6-10 years, $21.5 \%$ - $11-15$ years, $16.2 \%$ - 16-20 years, $4.3 \%$ - more than 20 years). Considering the size of the surveyed enterprises, the leaders of micro-enterprises represented the majority $(61 \%)$. They represent $2 / 3^{\text {rd }}$ of the respondents. 
The leaders of small companies represented $27 \%$ of the respondents, while $12 \%$ of the respondents represented the medium-sized enterprises.

In connection to our research assumption, we examined the opinion of the company leaders regarding the workplace atmosphere. The healthy workplace environment serves as a basis for smooth operation of business, increases the competitiveness on the market and helps to retain the staff. Most of the companies $(43 \%)$ reported a balanced workplace atmosphere. $29 \%$ of the surveyed businesses reported stressful workplace environment, while $28 \%$ described it rather relaxed. As a positive result, none of the companies indicated continuous stress and tension of the workplace environment.

As a further step, we examined the motivational tools applied by the surveyed companies.

Table 1

Sample characteristic $(\mathrm{N}=431)$ - years of companies establish and applied motivational tools

\begin{tabular}{|l|r|r|l|r|r|}
\hline Years & \multicolumn{1}{l|}{$\begin{array}{l}\text { \% } \\
\text { Valid \% }\end{array}$} & Applied motivational tools & \multicolumn{1}{l|}{ \% } & \multicolumn{1}{|l|}{ Valid \% } \\
\hline $0-5$ & 27.60 & 27.60 & financial benefits & 53.70 & 53.70 \\
\hline $6-10$ & 30.40 & 30.40 & verbal praise, recognitions & 29.60 & 29.60 \\
\hline $11-15$ & 21.50 & 21.50 & $\begin{array}{l}\text { carrier advancement } \\
\text { opportunities }\end{array}$ & 8.40 & 8.40 \\
\hline $16-20$ & 16.20 & 16.20 & non-material benefits & 7.60 & 7.60 \\
\hline $\begin{array}{l}\text { more } \\
\text { than } 20\end{array}$ & 4.30 & 4.30 & $\begin{array}{l}\text { prospect of penalties and } \\
\text { sanctions }\end{array}$ & 0.70 & 0.70 \\
\hline Total & $\mathbf{1 0 0 . 0 0}$ & $\mathbf{1 0 0 . 0 0}$ & Total & $\mathbf{1 0 0 . 0 0}$ & $\mathbf{1 0 0 . 0 0}$ \\
\hline
\end{tabular}

According to Table 1, the least motivating factors are penalties and sanctions. Only $0.7 \%$ of the respondents indicated this option. $8.4 \%$ of the leaders motivate with chance of promotion; $7.6 \%$ use non-financial incentives (e.g. entrance tickets, coupons) as a motivational tool. $29.6 \%$ of the leaders motivate with verbal praise and recognition. However, most of the leaders responded that financial incentive is still the most motivating factor (53.7\%). Employee motivation is closely linked to the corporate climate. If employees are motivated, they are trying to do their best, demoralization and fluctuation is decreasing, stress is falling and the competitiveness is increasing. The next 2 questions addressed the issue of team building within the company. If team building events are organized, how often and of how much importance is it to make the trainings popular among the employees. Well-organized team building programs help the company to function as a whole and focusing on how to exploit the hidden skills of the employee. The efficiency can drastically increase in the organization, where employees work as a team, pay attention and help each other. Cooperation and respecting each other reduces the chance of burnout. 
$55 \%$ of the surveyed company leaders organize team building programs. $42 \%$ of these leaders organize the trainings annually, while $13 \%$ of them organize trainings every six months. $61.8 \%$ of the leaders organizing team building programs agree that employee satisfaction is important. Although the company leaders can see the team building events satisfactory, the opinion of employees about team building is not asked. $31.6 \%$ of the leaders conducting a survey in order to make their team building programs more colorful. $6.6 \%$ of the leaders organize team building, whether or not the employees are satisfied with the program.

In addition to team-building programs, an annual dinner is organized in most of the companies. The executives usually talk about the mission and vision of the company on annual dinner events, so the employees can feel the importance of their contribution to company success as well as how their contribution is related to the success of the company. This is a great opportunity for executives to express their appreciation to their employees. According to our study, $74 \%$ of the executives organize annual dinner.

Beside the importance of company atmosphere and team building events, we were interested in the employment policy applied in the companies. The executives had to evaluate 15 statements regarding their company on a 4-point Likert scale, where 1is disagreement with the statement and 4 is complete agreement with the statement. Which statement is characteristic for the company was determined by an average; standard deviation was used to gain accurate results; and relative standard deviation was used to express this value in percentage. In order to get the most frequently option, the mode was calculated (Table 2).

Table 2

Statistical analysis of the Likert scale

\begin{tabular}{|l|l|l|l|l|}
\hline \multicolumn{1}{|c|}{ Statement } & Mean & $\begin{array}{l}\text { Standard } \\
\text { Deviation }\end{array}$ & $\begin{array}{l}\text { Reative } \\
\text { Standard } \\
\text { Deviation }\end{array}$ & Mode \\
\hline $\begin{array}{l}\text { Employee well-being is important } \\
\text { (material and moral esteem) }\end{array}$ & 3.45 & 0.64 & $18.50 \%$ & 4 \\
$\begin{array}{l}\text { Work-life balance should be } \\
\text { encouraged } \\
\text { Employees must receive regular } \\
\text { confirmation of their work } \\
\text { There must be an excellent } \\
\text { relationship with all employees }\end{array}$ & 3.31 & 0.66 & $19.90 \%$ & 3 \\
$\begin{array}{l}\text { The employees are motivated } \\
\text { All employees are aware of their role } \\
\text { and responsibilities } \\
\text { The employees are loyal and } \\
\text { committed to the company }\end{array}$ & 3.5 .56 & 0.71 & $20.46 \%$ & 4 \\
\hline
\end{tabular}




\begin{tabular}{|c|c|c|c|c|}
\hline $\begin{array}{l}\text { Employees must be involved in issues } \\
\text { that affect their work }\end{array}$ & 3.08 & 0.87 & $28.19 \%$ & 4 \\
\hline $\begin{array}{l}\text { It is often that employees have to work } \\
\text { overtime }\end{array}$ & 2.46 & 0.88 & $35.63 \%$ & 2 \\
\hline A leader must be consistent & 3.86 & 0.35 & $8.99 \%$ & 4 \\
\hline $\begin{array}{l}\text { A leader must be a good conflict } \\
\text { handler }\end{array}$ & 3.88 & 0.32 & $8.38 \%$ & 4 \\
\hline $\begin{array}{l}\text { It is important for a leader to } \\
\text { continuously train himself / herself as a } \\
\text { leader }\end{array}$ & 3.52 & 0.61 & $17.27 \%$ & 4 \\
\hline $\begin{array}{l}\text { Employee satisfaction needs to be } \\
\text { measured regularly (quarterly or semi- } \\
\text { annually) }\end{array}$ & 2.53 & 0.84 & $33.28 \%$ & 2 \\
\hline $\begin{array}{l}\text { It should be recognize in time if an } \\
\text { employee is about to terminate }\end{array}$ & 2.97 & 0.84 & $28.35 \%$ & 3 \\
\hline $\begin{array}{l}\text { Labor shortages are not typical of the } \\
\text { economic sector represented by our } \\
\text { company }\end{array}$ & 1.99 & 0.95 & $47.93 \%$ & 1 \\
\hline
\end{tabular}

Source: Authors' analysis

The survey results reveal that executives address great importance to well-being of their employees. Most of them chose the highest option 4, the average was 3.45 and the relative standard deviation $18.50 \%$, which indicates a moderately variable sample for the statement. The healthy work-life balance is also supported, but option 3 was chosen by most of the executives. The standard deviation was below $20 \%$. It was also revealed that employees are provided a regular feedback about their performance; they have also agreed that maintaining excellent relationship with employees is also important. The executives feel their employees motivated, most of them chose option 3, the average was 3.24 and the relative standard deviation 21.88\%. Most of the employees are aware of their tasks and responsibilities in the company. According to executives, the employees are loyal to the company. Most of them chose option 3, the average was 3.09. The relative standard deviation was $26.33 \%$, which means that part of the employers chose option 2 . They do not seem to be confident about employee loyalty. Similar results were gained regarding the statement that the employees should be engaged in the issues related to their work. The mode calculation was 4 in this case. The average was 3.09; and the relative standard deviation $28.19 \%$. In case of overtime, the average was 2.46 , accompanied with a relative standard deviation of $35.63 \%$. It means that most of the executives chose option 2, but the results were close to option 3. It can be declared that the employees have to work overtime several times. The following three statements were about the executives. The leader should be consistent, good in conflict management and should be trained as a leader. The respondents completely agree with the first two statements. Similar results were achieved in both cases. Most of the respondents chose option 4, the average was close to 3.9 and the relative standard deviation below $9 \%$. It means that the executives are consistent and show willingness to solve conflicts. 
Statement 3 shows a slight deterioration of values. The executives find important to participate on leadership trainings. The most frequently chosen option was 4 , but the average decreased to 3.52 and the relative standard deviation increased to $17.27 \%$. The executives did not entirely agree with conducting an employee satisfaction survey. Most of them chose option 2, the average was 2.53 and the relative standard deviation $33.28 \%$. They also expressed disagreement with the statement that one has to recognize in time if an employee is about to terminate. It is true that most of the respondents chose option 3, which means that they agree with the statement, but the average was 2.97 , and the value of relative standard deviation $28.35 \%$. This result is high enough to remain close to choose option 2 . Our last statement was about the general labor shortage. The executives had to decide how much the labor shortage is characteristic in their sector. Most of the executives chose option 1 . The average (1.99) was high and the relative standard deviation was 47.93. According to most of the executives, the labor shortage is high, but we are closer to value 2 , which is considered moderately high. When examining the standard deviation, we should note that smaller the standard deviation is, the more the executives involved in the survey agree, so we can speak about a reliable average.

We have now reached the questions related to the fluctuation and termination of the employees. Our primary focus was on the average time employees stay with the company. $41.6 \%$ of the companies reported that employees are staying with the company for $1-3$ years, while $36.2 \%$ of the companies reported an average of 4-5 years. The maximum of 1 and 6-10 year intervals was reported by $9.1 \%$ and $9.7 \%$ of the companies, while an employee working 10 years for the company was reported by $3.4 \%$ of the companies (Table 3 ).

Table 3

Sample characteristic $(\mathrm{N}=431)$ - years of companies establish and average time employees are staying with the company

\begin{tabular}{|c|c|c|c|c|c|}
\hline Years & $\boldsymbol{\%}$ & Valid \% & $\begin{array}{c}\text { Average time employees are } \\
\text { staying with the company }\end{array}$ & $\boldsymbol{\%}$ & Valid \% \\
\hline $0-5$ & 27.60 & 27.60 & probation - 1 year & 9.10 & 9.10 \\
\hline $6-10$ & 30.40 & 30.40 & $1-3$ years & 41.60 & 41.60 \\
\hline $11-15$ & 21.50 & 21.50 & $4-5$ years & 36.20 & 36.20 \\
\hline $16-20$ & 16.20 & 16.20 & $6-10$ years & 9.70 & 9.70 \\
\hline $\begin{array}{c}\text { more than } \\
\text { 20 }\end{array}$ & 4.30 & 4.30 & more than 10 years & 3.40 & 3.40 \\
\hline Total & $\mathbf{1 0 0 . 0 0}$ & $\mathbf{1 0 0 . 0 0}$ & Total & $\mathbf{1 0 0 . 0 0}$ & $\mathbf{1 0 0 . 0 0}$ \\
\hline
\end{tabular}

Source: Authors' analysis

As a next step, we surveyed the reasons of the employee termination. There might be many reasons why employees are leaving the company. The most frequently chosen answer in this survey was the change in living circumstances of the employee $(31.5 \%)$. It was followed by low wage $(24.1 \%)$ and the lack of progress 
(18.3\%). $11.9 \%$ of the respondents reported the difficulty of work and $8.3 \%$ left because of the work conditions. Workplace grievances were mentioned by $5.9 \%$ of the respondents (Figure 3).

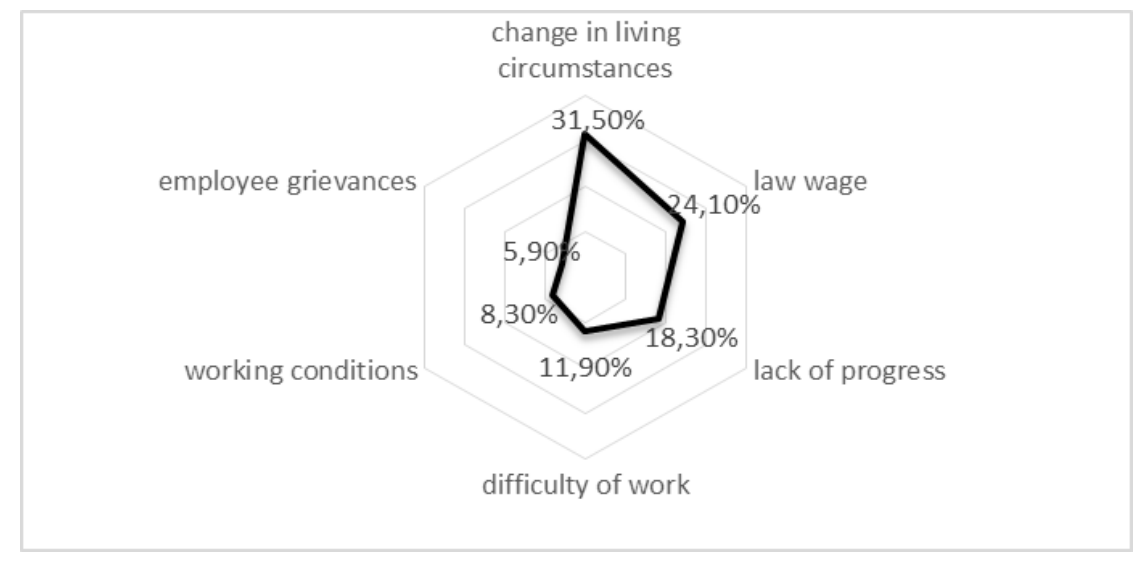

Figure 3

The most common reasons of employee termination

(Source: own editing based on primary data)

In terms of the research, we found it important to examine the fluctuation of the past 5 years in the companies. $45 \%$ of the companies reported $16-30 \%$ fluctuation, while $38 \%$ of them showed a fluctuation of $0-15 \% .12 \%$ of the companies faced $31-45 \%$ workforce fluctuation, while $5 \%$ of the companies reported workforce fluctuation over $45 \%$.

The fluctuation rate was compared to the motivational tools. We were interested in the level of the fluctuation at those companies where financial incentive is the main tool of motivation (Table 4).

Table 4

Table 3: Motivational tools vs workforce fluctuation

\begin{tabular}{|l|c|c|}
\hline $\begin{array}{l}\text { How you typically motivates your } \\
\text { employees? }\end{array}$ & $\begin{array}{l}\text { Fluctuation rate in the last 5 } \\
\text { years }\end{array}$ & Distribution \\
\hline Financial benefits & $0-15 \%$ & $15 \%$ \\
& $16-30 \%$ & $30 \%$ \\
& $31-45 \%$ & $7 \%$ \\
Financial benefits - Total & Over 45\% & $2 \%$ \\
Penalties, sanctions & & $\mathbf{5 4 \%}$ \\
Penalties, sanctions -Total & $31-45 \%$ & $1 \%$ \\
Career advancement opportunities & & $\mathbf{1 \%}$ \\
& $0-15 \%$ & $2 \%$ \\
\hline
\end{tabular}




\begin{tabular}{|l|c|c|}
\hline & $31-45 \%$ & $1 \%$ \\
Career advancement opportunities - & Over 45\% & $2 \%$ \\
Total & & $\mathbf{8 \%}$ \\
Non-material benefits & $0-15 \%$ & $3 \%$ \\
& $16-30 \%$ & $4 \%$ \\
Non-material benefits - Total & & $\mathbf{7 \%}$ \\
Verbal praise, recognition & $0-15 \%$ & $18 \%$ \\
& $16-30 \%$ & $8 \%$ \\
& $31-45 \%$ & $3 \%$ \\
Verbal praise, recognition - Total & Over $45 \%$ & $1 \%$ \\
TOTAL & & $\mathbf{3 0 \%}$ \\
\hline
\end{tabular}

(Source: own editing based on primary data)

We can summarize that $54 \%$ of the SMEs use financial incentive as a motivational tool. $39 \%$ of these companies reported higher than $15 \%$ workforce fluctuation. It means that they fall into the higher category. The executives using financial incentive as a motivational tool have to face high workforce fluctuation.

The purpose of this study was to examine the efforts the companies make to prevent burnout. As it is known from collected data, 55\% of the companies organize team building programs, however $4 \%$ of these companies organize team building as a necessary company occasion. We can sum up that $51 \%$ of the companies emphasize the importance of team building programs. The executives of the company used a 4-point Likert scale, where 1 is absolutely disagree and 4 is absolutely agree. The answers provided for individual statements are introduced in groups.

Table 5

Prevention of burnout syndrome (\%)

\begin{tabular}{|c|c|c|c|c|}
\hline Statement & 1 & 2 & 3 & 4 \\
\hline $\begin{array}{l}\text { Employee well-being is important (material and } \\
\text { moral esteem) }\end{array}$ & \multicolumn{2}{|c|}{$6 \%$} & \multicolumn{2}{|c|}{$94 \%$} \\
\hline Work-life balance should be encouraged & \multicolumn{2}{|c|}{$11 \%$} & \multicolumn{2}{|c|}{$89 \%$} \\
\hline $\begin{array}{l}\text { Employees must receive regular confirmation of } \\
\text { their work }\end{array}$ & \multicolumn{2}{|c|}{$9 \%$} & \multicolumn{2}{|c|}{$91 \%$} \\
\hline $\begin{array}{l}\text { All employees are aware of their role and } \\
\text { responsibilities }\end{array}$ & \multicolumn{2}{|c|}{$6 \%$} & \multicolumn{2}{|c|}{$94 \%$} \\
\hline It is often that employees have to work overtime & \multicolumn{2}{|c|}{$58 \%$} & \multicolumn{2}{|c|}{$42 \%$} \\
\hline $\begin{array}{l}\text { Employee satisfaction needs to be measured } \\
\text { regularly (quarterly or semi-annually) }\end{array}$ & \multicolumn{2}{|c|}{$52 \%$} & \multicolumn{2}{|c|}{$48 \%$} \\
\hline The employees are motivated & \multicolumn{2}{|c|}{$14 \%$} & \multicolumn{2}{|c|}{$86 \%$} \\
\hline
\end{tabular}


It can be summarized that $94 \%$ of the surveyed companies find important the employee well-being (financial and moral appreciation), while $89 \%$ of the companies agree with the supporting the work-life balance. The regular employee feedback is supported by $91 \%$ of the executives. $94 \%$ of the executive's agree that employees have to be aware of their tasks and responsibilities. 58\% of the companies have no regular overtime. $48 \%$ of the executives conduct employee satisfaction survey on regular basis. $80 \%$ of the companies reported employee satisfaction.

Based on calculations of average and standard deviation, $76.38 \%$ of the companies introduce measures against burnout. The standard deviation (not the relative standard deviation) is high (18.95\%).

In order to test our assumption, the $\mathrm{H}_{0}$ Hypothesis was formulated, as an alternative we formulated $\mathrm{H}_{1}$ hypothesis.

$\mathrm{H}_{0}$ : There is no significant correlation between the motivational tools used in SMEs and the prevention of burnout syndrome.

$\mathrm{H}_{1}$ : There is a significant correlation between the motivational tools used in SMEs and the prevention of burnout syndrome.

The Pearson Chi square table is used to show the correlation between the variables. The observed value of the indicator is 30.429 . The value at two-tailed significance test is lower than 0.05. It means, that Hypothesis $0-$ there is no significant correlation between the variables - can be rejected.

Table 6

Pearson's Chi-square Test

\begin{tabular}{|l|c|c|c|}
\hline & Value & df & $\begin{array}{c}\text { Asymp. Sig. (2- } \\
\text { sided) }\end{array}$ \\
\hline Pearson Chi-Square & 30.429 & 7 & 0.000 \\
N of Valid Cases & 431 & & \\
\hline
\end{tabular}

(Source: own editing based on primary data)

To analyze the strength of association between two nominal variables based on Pearson's Chi-square statistics we used Cramer V indicator.

Table 7

Value of Cramer V about the prevention of burnout syndrome

\begin{tabular}{|l|c|r|}
\hline & Cramer V & Approx.Sig. \\
\hline Prevention of burnout syndrome & 0.159 & 0.000 \\
\hline
\end{tabular}

(Source: own editing based on primary data)

According of value of Cramer $\mathrm{V}$ the association between the motivational tools used in SMEs and the prevention of burnout syndrome is greater than medium, so 
we consider widespread use of motivation tools in SMEs, because they have a statistically significant positive effect on the prevention of burnout syndrome.

\section{Conclusions}

According to our study, the most difficult recruitment problem is hiring a motivated workforce. The general labor shortage was only the second problem indicated. Surprisingly, Executives are missing the appropriately motivated staff. We believe that the employees have to be motivated by the Executives, as it is very rare that SMEs own a brand similar to multinational companies, where the candidate is motivated by chance to work for a company with a well-known brand. Addressing the issue of motivation, it has also turned out that $54 \%$ of the employers still find financial incentive the most motivating tool. The employees are considered to be motivated and committed to company values (Likert scale). However, the companies using financial incentive as a motivation tool experience higher employee fluctuation.

Based on the obtained data about burnout syndrome, we can conclude that $76.38 \%$ of the surveyed companies address the issue of employee burnout. The achieved result is good despite a standard deviation of $18.95 \%$. The scientific literature has reported a much poorer rate than the survey results. As the survey results show, $86 \%$ of the employees are at risk of burnout, since burnout is the disease of our moder civilization.

Workforce retention is still a serious problem for the SME sector. 68\% of the companies fight with more than $15 \%$ workforce fluctuations, which can be a knowledged as a loss for the company. It is important the company Executives recognize appropriate motivational tools, the importance of atypical employment patterns and team building programs in order to become more competitive and profitable in the future.

In order to make practical suggestions based on the results of our research HR managers need to delve deeper into the characteristics of the different generations present in the labor market based on these their motivational factors. The aim of the present article is not to map the motivational factors in detail for different generations, but it can be generally stated that there are three major HR challenges connected with generational differences (attract and retain while working, the changing nature of work and careers and career achievement). [26] For Generation $\mathrm{Y}$ it is characteristic, that their promotion self-enhancement in terms of valuing money and promotion is also viewed as an advancement at the workplace, etc. Generation $\mathrm{Z}$ have been found to hold stronger similar and even the same values most prominently. [4]

The limitation of the research can basically be identified in the elements of the sample. In order to show more accurate results, it is necessary to increase the number of elements in the sample. In future research the aim will be to cover a detailed and more comprehensive study from the point of view of generations in 
order to avoid burnout-syndrome. The problem can also be explored in terms of cultural differences.

\section{References}

[1] Belás, J. et al. (2014) Business risk and the level of entrepreneurial optimism of SMEs in the Czech and Slovak Republic. Journal of competitiveness, 2014, 6(2), pp. 30-41

[2] Belás, J.; Bilan, Y.; Demjan, V.; Sipko, J. (2015) Entrepreneurship in SME Segment: case study from the Czech Republic and Slovakia. Amfiteatru Economic. 2015, 17 (38), pp. 308-326

[3] Bertalan, P.; Boldizsár, B. (2015) Globális trendek és a HR. Acta Scientiarum Socialium. 2015, 44.(1), pp. 151-160

[4] Črešnar, R.; Nedelko, Z. (2020) Understanding Future Leadres: How Are Personal Values of Generations Y and Z Tailored to Leadership in Industry 4.0? Sustainability, 12, 4417, doi: 10.3390/su12114417

[5] Csehné, P. I. (2011) Foglalkoztatáspolitika. (Employment policy) [online] Szent István University. Available on the internet https://webcache.googleusercontent.com/search?q=cache:STTQCUJ0u5M J:https://www.tankonyvtar.hu/hu/tartalom/tamop412A/20100019_foglalkoztataspolitika/20100019_foglalkoztataspolitika.pdf $+\& \mathrm{~cd}=1 \& \mathrm{hl}=\mathrm{hu} \& \mathrm{ct}=\mathrm{clnk} \& \mathrm{gl}=\mathrm{hu}$

[6] Dobák, M. (2008) Szervezeti formák és vezetés. (Organizational forms and leadership) Akadémiai Kiadó (Publisher) 2008, 264 p

[7] Eccles, R. G.; Perkins, K. M.; Serafeim, G. (2012) How to Become a Sustainable Company. Mit Sloan Management Review. 2012, 53 (4), pp. 43-51

[8] Gašparíková, J.; Brzica, D.; Nemcová, E. (2004) The Impact of Industrial and Regional Differentiation on SMEs in Slovak Republic. Ekonomický časopis (Economic Journal), 2004, 52 (7), pp. 820-834

[9] Gravetter, J. F. - Wallnau, L. B. (2013) Statistics for the Behavioral Science, $9^{\text {th }}$ Edition, Cengage Learning, $615 \mathrm{p}$.

[10] Ivanová, E. (2017) Barriers to the Development of SMEs in the Slovak Republic. Oeconomica Copernicana, 2017, 8 (2), pp. 255-272

[11] Kollár, Cs.: A munkahelyi kiégés (burnout szindróma) elméleti megközelítése, kutatási irányai és közgazdaságtudományi aspektusa. (Theoretical approach, research directions and economic aspects of burnout syndrome) Fluentum, 2014, 1 (3), pp. 1-19

[12] Kozubíková, L. et al. (2015) Personal characteristics of entreúreneursin the context of perceptions and management ob business risk in the SME segment. Economics \& Sociology, 2015, 8 (1), pp. 41-54 
[13] Lazíková, J.; Bandlerová, A.; Roháčiková, O.; Schwarcz, P.; Rumnovska, L. (2018) Regional Disparities of Small and Medium Enterprises in Slovakia. Acta Polytechnica Hungarica, 2018, 15 (8)

[14] Lazányi, K. (2014) Entrepreneurs of the future. Serbian Journal of Management. 2014, 9 (2), pp.149-158, doi: 10.5937/sjm9-6257

[15] Lesáková, L. (2009) Innovations in Small and Medium Enterprises in Slovakia. Acta Polytechnika Hungarica, 2009, 6 (3), pp. 23-34

[16] Lipták, K. (2009) Foglalkoztatáspolitika Magyarországon, különös tekintettel az időskorúak foglalkoztatására. (Employment policy in Hungary, with special regard to the employment of elderly) Északmagyarországi Stratégiai Füzetek. (Northern Hungary Strategic Booklets) 2009, 6(1), pp. 3-16

[17] Maslach, C.; Goldberg, J. (1998) Prevention of Burnout: New Perspectives. Applied \& Preventive Psychology, 7 (1), 63-74

[18] Maslow, A. (1954) Motivation and personality. Harper\&Row. 1954, 411 p.

[19] Mura, L.; Ključnikov, A.; Tvaronavičiene, M.; Androniceanu, A. (2017) Development Trends in Human Resource Management in Small and Medium Enterprises in the Visegrad Group. Acta Polytechnica Hungarica, 2017, 14 (7)

[20] Nikodijevic, A.; Andelkovic Labrovic, J.; Dokovic, A. (2012) Academic Burnout Among Students at Faculty of Organizational Sciences. Journal for Theory and Managemet. 2012, 64, pp. 47-53, doi: 10.7595/management.fon.2012.0019

[21] Petrů, N.; Havlíček, K. (2017) Family Entrepreneurship in the Czech Republic on the Verge of First Generation Handover. Journal of International Studies. 2017, 10 (4), pp. 119-130, doi: 10.14254/20718330.2017/10-4/9

[22] Piac\&Profit. (2015) Kiégtek, stresszesek a magyar munkavállalók. (The Hungarian workers are burned out and stressed) [online] Piac\&Profit. 2015, Available on the internet: https://piacesprofit.hu/kkv_cegblog/ kiegtek-stresszesek-a-magyar-munkavallalok/

[23] Pink, D. H. (2009) Drive: The Surprising Truth About What Motivates Us. $1^{\text {st }}$ edition. Riverhead Hardcover. 2009, 256 p.

[24] Rajnoha, R.; Dobrovič, J. (2016) The Globalization of Business Management in Slovac Companies. Proceeding of MANAGEMENT 2016: $6^{\text {th }}$ International Scientific Conference on International Business and Management, Domestic Particularities and Emerging Markets in the Light of Research. Prešov, 2016, pp. 291-296

[25] Sebök, M. (2018) A munka világa a 21. század elején. (The world of work at the beginning of the $21^{\text {st }}$ Century) Saxum Kiadó (Publisher) 2018, $431 \mathrm{p}$. 
[26] S.W. Ng, E.; Parry, E. (2016) Multigenerational Research in Human Resource Management. In. Review in Personnel and Human Resources Management, pp. 1-41, ISBN 978-1-78635-264-4, doi: 10.1108/S0742730120160000034008

[27] Tandari-Kovács, M. (2010) Érzelmi megterhelődés, lelki kiégés az egészségügyi dolgozók körében. (Emotional strain, mental burnout among healthcare workers) Doctoral dissertation. Semmelweis University 2010, $167 \mathrm{p}$. 